Correction

\title{
Correction: Rana, P., et al. Training Area Concept in a Two-Phase Biomass Inventory Using Airborne Laser Scanning and RapidEye Satellite Data. Remote Sens. 2014, 6, 285-309
}

\section{Parvez Rana $^{1, *}$, Timo Tokola ${ }^{1}$, Lauri Korhonen ${ }^{1}$, Qing Xu ${ }^{1}$, Timo Kumpula ${ }^{2}$, Petteri Vihervaara ${ }^{3}$ and Laura Mononen ${ }^{3}$}

1 School of Forest Sciences, University of Eastern Finland, P.O. Box-111, Joensuu 80101, Finland; E-Mails: timo.tokola@uef.fi (T.T.); lauri.korhonen@uef.fi (L.K.); Qing.Xu@uef.fi (Q.X.)

2 Department of Geographical and Historical Studies, University of Eastern Finland, Yliopistonkatu 7, Joensuu 80101, Finland; E-Mail: timo.kumpula@uef.fi

3 Finnish Environment Institute (SYKE), Natural Environment Centre, Ecosystem Change Unit, P.O. Box 111, Yliopistokatu 7 (Natura), Joensuu 80101, Finland;

E-Mails: petteri.vihervaara@ymparisto.fi (P.V.); laura.mononen@ymparisto.fi (L.M.)

* Author to whom correspondence should be addressed; E-Mail: parvez_200207@yahoo.com; Tel.: +358-50-3723-942; Fax: +358-29-4457-316.

Received: 3 August 2015 / Accepted: 7 August 2015 / Published: 11 August 2015

Due to an oversight by the authors there is a correction necessary in this publication [1]. We would like to change the word "phase" to "step" throughout the manuscript. We apologize for any inconvenience caused to readers.

\section{Reference}

1. Rana, P.; Tokola, T.; Korhonen, L.; Xu, Q.; Kumpula, T.; Vihervaara, P.; Mononen, L. Training area concept in a two-phase biomass inventory using airborne laser scanning and RapidEye satellite data. Remote Sens. 2014, 6, 285-309.

(C) 2015 by the authors; licensee MDPI, Basel, Switzerland. This article is an open access article distributed under the terms and conditions of the Creative Commons Attribution license (http://creativecommons.org/licenses/by/4.0/). 